\title{
The marine environment: hazards, resources and the application of geoethics principles
}

\author{
Roberto A. Violante \\ Servicio de Hidrografía Naval, División Geología y Geofísica Marina, Buenos Aires, Argentina \\ GEVAS Red Argentina Asociación Civil \\ IAPG - International Association for Promoting Geoethics, Argentina \\ violante@hidro.gov.ar
}

GRAZIELLA BOZZANO

Servicio de Hidrografía Naval, División Geología y Geofísica Marina, Buenos Aires, Argentina Consejo Nacional de Investigaciones Científicas y Técnicas (CONICET), Buenos Aires, Argentina gbozzano@hidro.gov.ar

ELIZABETH I. ROVERE

Servicio Geológico Minero Argentino (SEGEMAR), Instituto de Geología y Recursos Minerales, Dir. Geología Ambiental y Aplicada, Buenos Aires, Argentina

GEVAS Red Argentina Asociación Civil

IAPG - International Association for Promoting Geoethics, Argentina

elizabeth.rovere@segemar.gov.ar

\begin{abstract}
Oceans cover three quarters of the Earth surface and represent a fundamental component of the global climate system. Life on Earth is closely tied to the climate system and thus to the oceans. Marine regions are subjected to numerous submarine natural hazards such as earthquakes, volcanic eruptions and landslides, in many cases producing tsunamis that threaten coastal areas and many onshore and offshore man-made facilities. On the other hand, as society and technological needs progressively increase, the impact of human activities on coastal and deep waters become more severe, with consequences that include global warming and sea-level rise, coastal erosion, pollution, ocean acidification, damage to marine resources and ecosystem degradation. Nevertheless, humankind seems not to be adequately conscious about the different kind of hazards threatening the marine environment. The challenge for marine geoscientists is to be conscious of the geoethical compromise in order to alert society, industries and policy makers about the needs to minimize the risks of natural and human impacts in the ocean system.
\end{abstract}

\section{INTRODUCTION}

ceans cover $71 \%$ of the Earth surface and account for $96.4 \%$ of the total water volume, providing the largest living space on the entire planet and producing about half of the global biospheric net primary production (Gregg et al., 2003). Oceans are part of the complex ocean-atmosphere coupling that regulates global climate, as they store most of the sun's energy, distribute heat around the planet and behave as a $\mathrm{CO}_{2}$ reservoir (Bigg et 
al., 2003). Therefore, life on Earth basically depends on oceans.

As a fragile environment, under a delicate balance between climate and marine physicalchemical processes, oceans are especially vulnerable to both natural and man-induced hazards. Natural hazards include submarine earthquakes and volcanic eruptions, landslides and other underwater gravity-driven processes, tsunamis and extreme oceanographic and climatic events like storms, hurricanes and waterspouts, among others. Man-induced threatening factors, responding either to misuse or negligence, encompass: a) coastal management and handling of offshore structures, such as industrial and touristic harbour operation, port-access channels dredging, coastal protection, deployment of oil rigs, submarine ducts and cables, and implementation of off-shore renewable marine energy farms; b) overexploitation of living and non-living resources, with intense bottom trawling fishing activities and oil spills as the most dangerous; and c) ocean pollution, iron fertilization and chemical and solid waste dumping. Other hazards such as greenhouse gas emissions, global warming, sea-level rise and coastal erosion may have both natural and anthropic causes. Oceans respond to human impacts at different rates. For example, short/medium-term responses include modification of littoral processes, coastal erosion, coastal flooding, alteration of highly bio-productive nearshore areas (deltas, estuaries, wetlands) and threats to marine life. Longterm responses include sea-level rise, ocean acidification and alteration of seaw ater properties (temperature, salinity, oxygen) (Pörtner et al., 2014).

In general, hazards at coasts and sea are not adequately considered by the scientific community under a social perspective, and ethical principles are far from being applied in most of the cases. Thus, marine geosciences provide a vast field for integrating scientific knowledge and ethical principles, with the objective of developing a science-based, responsible and sustainable management strategies for such a large and fundamental environment.

The purpose of the present contribution is to synthesize some of the multiple issues related to natural and anthropic hazards at sea, as well as underlining the need for a geoethical approach for adequately evaluating environmental and social impacts on oceans. These are critical needs, considering that the use of the marine space, resources, and energy will be essential for future generations (UNCLOSS, 1982).

\section{GEOETHICS, RISK, HAZARD AND VULNERABILITY AT SEA}

Geoethical principles point to make geoscientists more aw are of their responsibilities in any situation where scientists interact with society (e.g.: Peppoloni and Di Capua, 2015; 2017). Among the fundamental values of geoethics listed in The Cape Town Statement on Geoethics (Di Capua et al., 2017), three are of specific interest for marine geoscience: (1) respecting natural processes and phenomena, where possible, when planning and implementing interventions in the marine environment; (2) ensuring sustainability of economic and social activities in order to assure future generations' supply of energy and other natural resources, and (3) promoting geo-education and outreach for all, to further sustainable economic development, geohazard prevention and mitigation, environmental protection and increased societal resilience and well-being.

The applications of geoethical principles on the ocean environment have been already discussed by several authors (e.g.: Safina, 2003, Dallmeyer, 2005, Zacharias and Gregr, 2005, Auster et al., 2008, Pauly and Stergiou, 2014, Marone et al., 2015). Zacharias and Gregr (2005) stated that all marine features (biotic and abiotic) have been formed and evolved within a certain range of environmental conditions, and therefore they are sensitive to diverse degrees of stress according to the interaction among hazard, vulnerability and exposure, terms already defined by Taubenböck et al. (2008) and Di Capua and Peppoloni (2014). Considering that the concept of risk depends upon the degree to which the hazards threaten vulnerable and exposed human facilities or resources, for marine environments it seems obvious that the highest risks are closest to inhabited coasts (E.g.: Dafforn et al., 2015). However, risk can also be high in deep-sea environments, particularly where fragile ocean ecosystems 
Table 1: General framework conceptualizing risk, hazard and vulnerability in the marine environment (modified after Taubenböck et al., 2008)

\begin{tabular}{|c|c|c|c|}
\hline TERMS & & CAUSES & PROCESSES \\
\hline & & Natural & $\begin{array}{l}\text { Earthquakes } \\
\text { Volcanic eruptions } \\
\text { Gravity-driven processes-land slides } \\
\text { Oceanographic changes } \\
\text { Large waves (including tsunamis) }\end{array}$ \\
\hline & 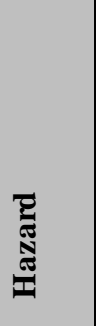 & $\begin{array}{l}\text { Natural } \\
\text { and/or } \\
\text { anthropic }\end{array}$ & $\begin{array}{l}\text { Climate change } \\
\text { Sea level rise } \\
\text { Coastal erosion } \\
\text { Coastal floods } \\
\text { Sea-water properties } \\
\text { Iron fertilization } \\
\text { Ocean acidification } \\
\text { Methane emissions }\end{array}$ \\
\hline$\frac{y}{a}$ & & Anthropic & $\begin{array}{l}\text { Coastal management } \\
\text { Urban and touristic facilities } \\
\text { Inshore and offshore man-made structures } \\
\text { Dredging } \\
\text { Facilities for marine renewable energies } \\
\text { Living and non-living resources exploitation } \\
\text { Mining } \\
\text { Fishing practices impacting sea-floor } \\
\text { Pollution (waste, plastic, oil disposal) }\end{array}$ \\
\hline & 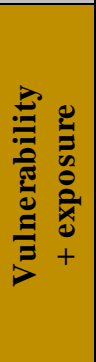 & $\begin{array}{l}\text { Physical, } \\
\text { social, } \\
\text { economic, eco- } \\
\text { logical }\end{array}$ & $\begin{array}{l}\text { Geography and topography } \\
\text { Location } \\
\text { Population } \\
\text { Social structure } \\
\text { Productive activities } \\
\text { Cultural heritage } \\
\text { Engineering structures and infrastructures } \\
\text { Environment } \\
\text { Living and non-living resources }\end{array}$ \\
\hline
\end{tabular}

and living resources have to coexist with offshore infrastructures and other man-induced impacts (for example pollution and bottomtraw ling fishery).

\section{MARINE NATURAL AND ANTHROPIC HAZARDS}

Oceans are so vast that in principle it would seem unlikely that a locally generated hazard in a coastal area could affect far deep-sea locations. However, the ocean circulation system transports water through all the ocean basins by both surface and deep-sea currents, so that dispersal of any component existing in the wa- ter mass (chemicals, pollutants) far away from the source can occur. On the other hand, the energy generated by deep-sea geological processes (e.g. submarine earthquakes, volcanic eruptions or underwater slides and slopes instabilities) can be transferred to surface waves, which can potentially be transformed in tsunamis that rapidly propagate across the seas. So, the marine environment can be considered as a system of communicating vessels transporting materials and energy all around the world.

Some of the natural and anthropic processes that may potentially represent a risk to oceans are listed in Tab. 1. Among them, earthquakes, 
volcanic eruptions and gravity-driven processes are natural hazards that cannot be prevented, but their impacts on society can be minimized if geoethical principles are applied at different stages of the risk management, like in the early warning, prevention and mitigation. After these processes, several human-induced hazards are discussed, and how these can be avoided if societies will reach the aw areness of the damage they mean.

\subsection{Submarine earthquakes}

They are some of the most dangerous natural processes at sea, because they are potential generators, among other impacts, of large waves inducing tsunamis. As the most striking example, the 9.1 magnitude submarine earthquake of Sumatra (2004) generated a complex series of tsunami waves that propagated at a speed of $640 \mathrm{~km} / \mathrm{h}$ producing a significant loss of lives, thousands of displaced or missing people and severe damages to the infrastructures, affecting the coasts of 12 nations around the Indian Ocean. Waves also travelled outside the Indian Ocean reaching areas very far aw ay in the Atlantic and Pacific Oceans (e.g.: Titov et al., 2005). In 2011, the 9.0 magnitude earthquake in northeastern Japan also induced a tsunami wave that hit and dramatically affected the region, including the destruction of the Fukushima Power Plant. The earthquakes of Chile of 2010 and 2015 also originated big tsunamis with waves as high as $11 \mathrm{~m}$ hitting not only the local shores but also the coasts of South America, California, New Zealand, Hawaii, Japan and many Pacific islands, with hundreds of deaths and thousands of destroyed houses. These examples show how the geoethic principles applied to the marine environment are important, especially when geohazards affect remote coastal areas and islands where emergencies require specific actions, which include social and political aw areness of the pre- and post-crisis management stages.

\subsection{Volcanism}

About $80 \%$ of the volcanic eruptions on Earth take place underwater, particularly in volcanic arcs associated with subduction zones and oth- er types of submarine volcanoes. However, volcanoes located in coastal regions and inhabited volcanic islands are also very important as they affect coastal communities. Volcanic eruptions close to the shore are able to trigger tsunamis (Egorov, 2007) through different mechanisms that include submarine lahars, caldera collapses, phreatomagmatic processes, among others. In this way, the volcanic hazard changes into a tsunami hazard, with the potential to impact regions far from the volcanic source. For example, the explosive eruption of Krakatoa in 1883 supplied several cubic kilometers of material that entered the sea displacing an equally huge volume of seawater, and producing a $45 \mathrm{~m}$ high tsunami wave that reached the coasts of South Africa (Egorov, 2007). The submerged volcano Protector Shoal in South Shetland Islands (1962) generated a submarine lahar that displaced $620 \times 10^{6} \mathrm{~m}^{3}$ of tephras inducing a big tsunami wave (Violante et al., 2014), with no adverse effects as it reached the uninhabited shores of Antarctica. The submarine eruption at El Hierro Island (Canarian Archipelago, Spain, 2011), occurred when the opening of a submarine vent and the onset of a fissure eruption at $900 \mathrm{~m}$ water depth and $5 \mathrm{~km}$ offshore the town of La Restinga, gave place to the ejection of volcanic bombs, ash and pyroclasts. In that occasion, the civil protection proceeded to a massive evacuation of the coastal populations that afterward resulted unnecessary with a negative impact on local economy (Carracedo et al., 2012). This is an example that shows the need of adequate early warnings and solid science-based recommendations for a proper crisis management. For explosive eruptions, the Volcanic Explosivity Index (Newhall et al., 2018) should be established by volcanologists in order to evaluate the magnitude of the eruptions, foresee the possible impacts, and advice authorities on the most reasonable responses and actions to implement.

\subsection{Gravity-driven mass transport}

Underwater turbiditic fluxes, slides and masstransport processes on steep slopes and in submarine canyons normally result from slope instabilities and collapses, although they can also be triggered by earthquakes and volcanic 
eruptions in many cases. These processes can damage underwater man-made structures, such as oil rigs, ducts and cables. In fact, turbidity currents were discovered after an earthquake offshore the coast of Terranova, Canada (1929) broke telegraphic cables in the ocean. An older well-known submarine slide is that of Storegga, in the Norwegian Sea, which occurred at 8,200 years BP as a consequence of a huge earthquake. This slide induced a series of tsunamis waves affecting numerous coastal areas in the North Sea, recording a maximum wave height of $20-30 \mathrm{~m}$ in the Shetland Islands (Bondevik et al., 2003). Like Storegga, many submarine slides and their associated tsunamis waves are acknowledged as important sources of geohazard with a vast impact on the safety both of peoples living on the coastal areas and of the offshore and onshore infrastructures (Masson et al., 2006).

\subsection{Sea-level rise and coastal retreat}

Present-day sea-level rise and coastal retreat may have both natural and human-induced causes. They are a concern as they strongly affect most populated coastal regions threatening both the littoral environment and human facilities. Observed mean sea level has risen between 17 and $21 \mathrm{~cm}$ since 1901 (Church et al., 2013) due to global warming, ocean thermal expansion and glaciers melt. These values represent an average annual increase of $1.7 \mathrm{~mm}$, although estimations for the last 25 years are much higher $(3.2 \mathrm{~mm} /$ year $)$. According to Nicholls et al. (2007), long-term global shoreline change rates are 50 to 200 times higher than sea-level rise, which means that $10 \mathrm{~cm}$ of sea-level increase would imply 5 to $20 \mathrm{~m}$ of coastal retreat. Of course, not only sea-level rise but also climate (e.g. through the energy of storms surges), urbanization, and humaninduced misuse of the shores promote coastal erosion, by altering the natural along-shore sediment transport and the equilibrium in the beach conditions. Therefore, the sustainable use of the littoral space is one of the important issues where geoethical principles should be applied, mainly through an adequate social awareness of its vulnerability and the implementation of shore protection management, which should be sustained by long-term policies aimed at to prevent or at least minimize the dramatic impact of climate change and man-made infrastructures upon coastal erosion and recession.

\subsection{Pollution}

Ocean pollution is another serious concern that humankind is facing today. The largest amount of pollutants at sea comes from activities on land, particularly dumping trash and litter, oil spills, chemicals and fertilizers. Products released from ships also contribute significantly. According to the information provided by NOAA (http:/ / www.noaa.gov/ resourcecollections/ ocean-pollution), 1.4 billion pounds of trash per year enter into the ocean. Plastic debris accumulates along and off the coasts in garbage patches as a result of ocean currents and local eddies, and microplastics have been found in deep-sea sediments (Woddal et al., 2014). Its pervasive presence in all oceans is a big issue as the impact on marine ecosystems and ultimately upon human health- has not been yet fully established. The time has come to better monitor the pollutants dispersal and disposal in the marine environment and deepsediments, to reduce land-based marine pollution by improving sewage and wastewater treatment, to educate youth and increase the public awareness through the media, and to influence the decision-making processes. Through these actions, our unsustainable consumption and production patterns may eventually change in the future (UNESCO, 2012).

\subsection{Ocean fertilization, acidification and eu- trophication}

Ocean fertilization (natural or man-induced) generally refers to supplying iron to the sea with significant impact on living resources (Wallace et al., 2010). Artificial fertilization used to increase phytoplankton to support fisheries, as well as fertilization techniques used to draw-down atmospheric $\mathrm{CO}_{2}$ (Jin et al., 2008) are clear examples of how ethical principles should be applied to prevent certain species from being harmed when others are intended to be benefited. Natural fertilization 
with iron sourced in rivers and airborne volcanic ash is an important feeder of oceanic surface waters (Duggen et al., 2010). This is a common process in the Southwestern Atlantic, where large amounts of iron-rich volcanic ashes from the Andean volcanoes are transported eastw ards by strong westerly winds, producing abnormal phytoplankton and algal blooms (Signorini et al., 2009) that in some cases might be harmful to marine faunas. Another problem is ocean acidification, which is the reduction of seawater $\mathrm{pH}$ due to increased atmospheric $\mathrm{CO}_{2}$. Oceans absorb more than $26 \%$ of the $\mathrm{CO}_{2}$ released to the atmosphere by greenhouse emission, and according to UNESCO (2012) oceans could become $150 \%$ more acidic than today by 2100 , which would cause dramatic acceleration in loss of biodiversity and irreversible ecological transformations. Eutrophication is the enrichment of seawater with excessive dissolved nutrients, which produces algal and phytoplankton blooms that may deplete and consume oxygen, with consequent damage to marine life (Ansari et al., 2011). According to Zacharias and Gregr (2005), oceans have suffered from a lack of quantitative methods aimed at delineating areas with different degrees of vulnerability. Thus, geoscientists should identify the regions where fragile ecosystems are especially under threat, monitor the occurrence of harmful blooms that might alter the marine fauna and imply a risk for human-health and foster the protection of the ocean and its living resources.

\subsection{Non-living resources exploitation}

As hydrocarbon exploration is expanding to previously inaccessible deep waters, potential water pollution and damage to ecosystems due to offshore exploration and drilling needs to be evaluated. Deep-sea seismic exploration usually employs airguns as a source of energy that produces pressure waves through the water column, which potentially disturbs marine faunas. Other, less-known but continuous contamination effects of offshore drilling operations consist in the disposal of drilling mud, brine wastes, deck runoff water and flow line and pipeline leaks. Catastrophic spills represent a serious threat for marine ecosystems.
Although more care and responsibility could limit the frequency of major accidents affecting offshore rigs, pipelines and oil storage, shipping routines and natural disasters put oil and gas exploitations at unpredictable risk. Another potential hazard is deep-sea mining, which consists of using massive machines to dredge and grind thousands of tons of rock at the sea floor to extract precious minerals (gold, copper, zinc, cobalt, manganese, titanium) from ore, hydrothermal and polymetallic nodule deposits. It represents an extremely expensive undertaking due to the technical challenges involved in retrieving large amounts of materials from great water depths. From a geoethical perspective, the balance between economic benefits and environmental and social impacts should be accurately estimated in order to avoid vast and irremediable damages to fragile and unique deep-sea life.

Ocean scientists, water experts and local communities should cooperate with government, private sector and policy makers to develop plans for sustainable environmental management as well as to promote the generation of legal and policy frameworks regulating the access to deep seabed resources (UNESCO, 2012). For the future, an increasing demand for nonenergy minerals is expected to support even the renewable green energies.

The point is whether a responsible deep-sea mining is possible or not. Local benthic communities, which are often extremely specialized, could permanently be damaged, and plumes of sediment driven by the dredging machines might potentially impact the whole water column by introducing chemical, noise and light pollution far away from the mining site.

Moreover, deep-sea mining includes added difficulties when compared to land-based extraction: restoration of sea-bottom after mining can be slower than land soil recovery, in the case that there is any chance to restore sea-bottom to the previous undisturbed conditions; the high costs to operate at great depths make company's good practice more expensive and thus less probable; finally, deep-sea ecosystems associated to hydrothermal vents are poorly known, and policies to preserve and restore these habitats are so far inadequate. 


\subsection{Living resources exploitation}

During the last 50 years, the ecosystems have been strongly modified by the increased human demand for food and energy. This is the first conclusion reached by "The Millennium Ecosystem Assessment" (https:/ / www.millenniumassessment.org/ en/ Synthesis.html, accessed 1 June 2018) that provides a state-of-the-art about the present-day conditions and deterioration of ecosystems worldwide. The industrial exploitation of the ocean's living resources is carried mainly by bottom trawling, which is a non-selective commercial fishing technique by which heavy nets and gear are pulled along the sea-floor with direct negative impacts not only on fish populations and benthic communities, but also on the sea-floor, as this practice affects and sometimes destroys the substratum where benthic and demersal species live and feed (Puig et al., 2012). Bottom trawling is a global, regular and harmful routine and thus the needs for applying ethical principles to minimize its impact and damage upon the environment are urgent. These might include: reduction of fishery effort by limiting the fleet motor power and promoting a more traditional way of fishing (trammels, little long lines and traps); education addressed to the society for a more responsible and sustainable consume of the living resources; respect of the natural processes (consume of seasonal species); implementation of policies that promote the protection of the marine environment in general and of specific vulnerable areas in particular (e.g. creating marine protected areas for fishing); and finally, launch of co-management processes, where fishermen, scientists and administration cooperate to maintain an healthy status of the stock.

\subsection{Marine energies}

Energy contained in waves, tides, currents and offshore winds, as well as that coming from high gradients of water properties (thermal and osmotic energy) can be feasibly converted into electricity. Their facilities include floating devices or anchored buoys that catch the energy of the waves, tidal turbines associated to dams or barrages built at estuaries or at the passages between islands and archipelagos, and wind farms with turbine towers anchored to the ocean floor. Although many countries are investing today in renewable technologies (UNESCO, 2017; Yang and Copping, 2017) the offshore structures that these technologies need are considerably expensive. In addition, they often significantly impact the local environment. For example, windmills may alter birds migratory corridors, tidal turbines may have a negative effect on marine faunas, and large wave energy structures may limit the mixing of the upper layers of sea-waters which could adversely impact marine life and fisheries, leading to the displacement and alteration of ecosystems. On the other hand, ideal spots for their installation are not as numerous as one can expect, for example most marine regions cannot be exploited because they are too far remote and the costs of construction and cabling the power to the grid would be prohibitive. Although oceanic renewable energy is today a feasible technology, environmental impact assessments, facilities lifetime prediction, structures rupture and costs-benefits evaluations need to be estimated under a geoethical perspective to develop a sustainable potential for their implementation.

\section{CONCLUSIONS}

The application of geoethical principles at sea in the context of natural and human-induced hazards is a novel concept. These principles have been traditionally applied to land-based problems, perhaps because continents are where people live and where well-known geohazards (earthquakes, volcanic eruptions, floodings, droughts, etc.) most commonly affect every-day life of thousands of people. On the other hand, there is a general perception about the oceans as a "waterworld" containing nothing but water, or at most endless fisheries, with no evident hazards. Both coastal and deep waters are subjected to increasing pressure from human infrastructures and activities without a clear aw areness of the potential risks. Tsunamis may be the best-known natural hazard related to the sea, but other sources of potential damages come from submarine earthquakes, volcanic eruptions and gravity- 
induced sedimentary processes, which can affect not only the coastal regions but also many offshore human facilities like oil rigs, ducts and submarine cables. Man-induced pollution and overexploitation of living and non-living resources are other hazards that threaten the fragile oceanic ecosystem. Marine currents are effective agents that transport sediments, pollutants and energy across the ocean basins. With the searching of new resources and technologies, the sea is considered as the main supplier of food and energy for the near future.

The comprehension of the marine environment is essential for protecting humans from oceansourced hazards, and geoethical principles can be suitable applied on a wide range of cases. In order to prevent the impact of man-made facilities and infrastructures on the marine environment, human interventions should be done within the respect of the natural processes and phenomena of the ocean; to prevent the marine environment deterioration, and for the future generations' benefit, energy and natural resources of the oceans should be used in a sustainable way, avoiding pollution and overexploitation; to minimize the risks and to save lives, geohazard prevention and mitigation, environmental protection and increased societal resilience and well-being could be achieved through a correct early warning mechanisms and a geo-education addressed to society and policy makers, so as to apply the most reasonable responses and actions when a geohazard is approaching.

\section{ACKNOWLEDGEMENTS}

Authors thank Giuseppe Di Capua and Silvia Peppoloni for inviting and encouraging us to write this contribution. We are indebted to three anonymous reviewers for their valuable corrections, comments, suggestions and recommendations that helped us to substantially improve the quality of the paper. Anna Bozzano contributed to the section "Living resources exploitation".

\section{REFERENCES}

Ansari A.A., Gill S.S., Lanza G.R. and Rast W. (2011). Eutrophication: Causes, Consequences and Control. Springer Sci-
ence+Business Media B.V.: 394 pp, doi 10.1007/ 978-90-481-9625-8.

Auster P.J., Fujita R., Kellert S.R., Avise J., Campagna C., Cuker B., Dayton P., Heneman B., Kenchington R., Stone G., Notarbartolo Di Sciara G. and Glynn P. (2008). Developing an Ocean Ethic: Science, Utility, Aesthetics, SelfInterest, and Different Ways of Knowing. Conservation Biology 23 (1): 233-235.

Bigg G.R., Jickells T.D., Liss P.S. and Osborn T.J. (2003). The role of the oceans in climate. International Journal of Climatology 23: 1127-1159. doi: $10.1002 /$ joc.926

Bondevik S., Mangerud J., Dawson S., Daw son A. and Lohne $\varnothing$. (2003). Record-breaking height for 8000-year old tsunami in the North Atlantic. EOS 84, 289-293.

Carracedo J.C., Pérez Torrado F., Rodríguez González A., Soler V., Fernández Turiel J.L., Troll V.R. and Wiesmaier S. (2012). The 2011 submarine volcanic eruption in El Hierro (Canary Islands). Geology Today. The Geologists' Association \& The Geological Society of London, Blackwell Publishing Ltd. 28 (2): 53-58.

Church J.A., Clark P.U., Cazenave A., Gregory J.M., Jevrejeva S., Levermann A., Merrifield M.A., Milne G.A., Nerem R.S., Nunn P.D., Payne A.J., Pfeffer W.T., Stammer D. and Unnikrishnan A.S. (2013). Sea Level Change. In: Climate Change 2013: The Physical Science Basis. Working Group I Contribution to the Fifth Assessment Report of the Intergovernmental Panel on Climate Change, Cambridge University Press, 1137-1216.

Dafforn K.A., Mayer-Pinto M., Morris R.L. and Waltham N.J. (2015). Application of management tools to integrate ecological principles with the design of marine infrastructure. Journal of Environmental Management 158: 61-73.

Dallmeyer D.G. (2005). Tow ard a sea ethic. In: Norse E.A. and Crowder L.B. (Eds.). Marine Conservation Biology: The Science of Maintaining the Sea's Biodiversity, Island Press, Washington, 410-421.

Di Capua G. and Peppoloni S. (2014). Geoethical Aspects in the Natural Hazards Management. In: Lollino G., et al. (Eds.). Engineering Geology for Society and Territory Springer International Publishing Switzerland, 59-62., doi: 10.1007/ 978-3-319-09303-1-11. 
Di Capua G., Peppoloni S. and Bobrow sky P.T. (2017). The Cape Town Statement on Geoethics. Annals of Geophysics, Vol. 60, Fast Track 7, doi: $10.4401 /$ ag-7553.

Duggen, S., Olgun, N., Croot, P., Hoffmann, L., Dietze, H., Delmelle, P. and Teschner, C. (2010). The role of airborne volcanic ash for the surface ocean biogeochemical iron-cycle: a review. Biogeosciences 7: 827-844.

Egorov Y. (2007). Tsunami wave generation by the eruption of underwater volcan. Nat. Hazard s Earth Syst. Sci. 7: 65-69.

Gregg W.W., Conkright M.E., Ginoux P., O’Reilly J.E. and Casey N.W. (2003). Ocean primary production and climate: Global decadal changes. Geophysical Research Letters 30 (15): 1809. doi:10.1029/2003GL016889.

Jin X., Gruber N., Frenzel H., Doney S.C. and McWilliams J.C. (2008). The impact on atmospheric $\mathrm{CO}_{2}$ of iron fertilization induced changes in the ocean's biological pump. Biogeosciences 5, 385-406

Marone E., Camargo R. and Salcedo-Castro J. (2015). Communicating natural hazards: marine extreme events and the importance of variability and forecast errors. In: Peppoloni S. and Di Capua G. (Eds.). Geoethics: the Role and Responsibility of Geoscientists Geological Society, Lond on, Special Publication 419, 125131.

Masson D.G., Harbitz C.B., Wynn R.B., Pedersen G. and Løvholt F. (2006). Philos Trans A Math Phys Eng Sci. 364(1845), 2009-2039. DOI: 10.1098/ rsta.2006.1810

Newhall C., Self S., and Robock A. (2018). Anticipating future Volcanic Explosivity Index (VEI) 7 eruptions and their chilling impacts. Geosphere $14 \quad$ (2): 572-603. doi: https:/ / doi.org/ 10.1130/ GES01513.1.

Nicholls R.J., Wong P.P., Burkett V.R., Codignotto J.O., Hay J.E., McLean R.F., Ragoonaden S., and Woodroffe C.D. (2007). Coastal systems and low-lying areas. In: Parry M.L., et al. (Eds.). Climate Change 2007: Impacts, Adaptation and Vulnerability. Contribution of Working Group II to the Fourth Assessment Report of the Intergovernmental Panel on Climate Change Cambridge University Press, 315-356.

Pauly D. and Stergiou K.I. (2014). The ethics of human impacts and the future of the earth's ecosystems: Introduction. Ethics in Science and Environmental Politics 14: 1-5.

Peppoloni S. and Di Capua G. (2015). The Meaning of Geoethics. In: Wyss M. and Peppoloni S. (Eds.). Geoethics: Ethical challenges and case studies in earth science. Elsevier, Massachusetts, 3-14. doi 10.1016/ B978-0-12-7999357.00001-0.

Peppoloni S. and Di Capua G. (2017). Geoethics: ethical, social and cultural implications in geosciences. In: Peppoloni S., Di Capua G., Bobrow sky P.T., Cronin V. (Eds.). Geoethics: at the heart of all geosciences. Annals of Geophysics, 2017, Vol 60, Fast Track 7, doi: 10.4401/ ag-7473.

Pörtner H.-O., Karl D.M., Boyd P.W., Cheung W.W.L., Lluch-Cota S.E., Nojiri Y., Schmidt D.N., and Zavialov P.O. (2014). Ocean systems. In: Climate Change 2014: Impacts, Adaptation, and Vulnerability. Part A: Global and Sectoral Aspects. Contribution of Working Group II to the Fifth Assessment Report of the Intergovernmental Panel on Climate Change, Cambridge University Press, 411-484.

Puig P., Canals M., Company J.B., Martín J., Amblas D., Lastras G., Palanques A., and Calafat A.M. (2012). Ploughing the deep sea floor. Nature 489: 286-290.

Safina C. (2003). Launching a Sea Ethic. Wild Earth. Winter 2002-2003: 2-5.

Signorini S.R., García V.M.T., Piola A.R., Evangelista H., McClain C.R., García C.A.E., and Mata M.M. (2009). Further studies on the physical and biogeochemical causes for large interannual changes in the Patagonian shelf springsummer phytoplankton bloom biomass. NASA/ TM-2009-214176.

Taubenböck H., Post J., Roth A., Zosseder K., Strunz G., and Dech S. (2008). A conceptual vulnerability and risk framew ork as outline to identify capabilities of remote sensing. Natural Hazards and Earth Systems Sciences 8 (3): 409-420.

Titov V., Rabinovich A., Mofjeld H., Thomson R., and González F. (2005). The global reach of the 26 December 2004 Sumatra tsunami. Science, 309:2045-2048.

UNCLOSS (1982). United Nations Convention on the Law of the Sea. Division for Ocean Affairs and the Law of the Sea, Office of Legal Affairs, United Nations. Version 2013 
http:/ / www.un.org/ depts/ los/ convention_agr eements/convention_overview_convention.htm. UNESCO (2012). Healthy Ocean, Healthy People. Rio+20 United Nations Conference on Sustainable Development. UNESCO. http:/ / www.unesco.org/ new/ en/ rioplus 20.

UNESCO (2017). 2nd. Int. Conference on Marine/ Maritime Spacial Planning. Intergovernmental Oceanographic Commission and European Oceanographic Commission. DGMARE 2017, Paris, France, IOC Workshop Reports Series 279.

Violante R.A., Cavallotto J.L., Rovere E.I., Dragani W.C., and Spoltore D.V. (2014). La problemática del riesgo ambiental en los ambientes marinos de Argentina. In: Goso C. (Ed.). Nuevas miradas a la problemática de los ambientes costeros, Sur de Brasil, Uruguay y Argentina. DIRAC, Montevideo, 231-256.

Wallace D.W.R., Law C.S., Boyd P.W., Collos Y., Croot P., Denman K., Lam P.J. Riebesell U., Takeda S., and Williamson P. (2010). Ocean Fertilization. A Scientific Summary for Policy Makers. IOC/ UNESCO, Paris (IOC/ BRO/ 2010/ 2).

Woodall L.C., Sanchez-Vidal A., Canals M., Paterson G.L.J., Coppock R., Sleight V., Calafat A., Rogers A.D., Narayanaswamy B.E., and Thompson R.C. (2014). The deep sea is a major sink for microplastic debris. Royal Soc.Open Science 1:140317, http:/ / d x.doi.org/ 10.1098/ rsos.140317.

Yang Z. and Copping A. (2017). Marine Renew able Energies. Springer Nature, Switzerland, 390 pp. doi: 10.1007.978-3-319-53536-4.

Zacharias M. and Gregr E. (2005). Sensitivity and Vulnerability in Marine Environments: an Approach to Identifying Vulnerable Marine Areas. Conservation Biology 19 (1): 86-97. 